\title{
Confirmatory Studies in the Prenatal Diagnosis of Sphingolipidoses
}

\author{
Alan K. Percy, ${ }^{[28]}$ Karen Miller, and Marguerite Sonneborn \\ Department of Neurology, Johns Hopkins University, School of Medicine, Baltimore, Maryland, USA \\ Michael M. Kaback \\ Department of Pediatrics, Johns Hopkins University, School of Medicine, Baltimore, Maryland, USA
}

\section{Extract}

Chemical and biochemical variables of the sphingolipids were examined in fetal liver, kidney, and brain using saline-aborted (SA) and hysterotomy-aborted (HA) tissues. Brain sphingolipid hexose (BSH) and ganglioside $N$-acetyl neuraminic acid (NANA) content were similar in each group (BSH/SA, $4.1-5.0 \mathrm{mg} / \mathrm{g}$ dry wt and HA, 3.0-6.7 mg/g dry wt; NANA/SA, 1.1-3.3 mg/g dry wt and HA, $1.3-3.1 \mathrm{mg} / \mathrm{g}$ dry $\mathrm{wt}$ ). The distribution of the major gangliosides was also comparable in each group. Sulfatide levels were lower in the hysterotomy group (0.2-0.4 $\mathrm{mg} / \mathrm{g}$ dry wt) than in the saline group $(0.5-0.9 \mathrm{mg} / \mathrm{g}$ dry $\mathrm{wt})$, perhaps reflecting the earlier gestational age of this group. Activities of arylsulfatase A (ARA), $\beta$-galactosidase, and hexosaminidase A from each tissue were similar, respectively, in salineand hysterotomy-aborted fetuses. The ARA activity (liver, 23-67; kidney, 13-21; and brain, $1-42 \mathrm{nmol}$ cleaved $/ \mathrm{mg}$ protein $/ \mathrm{hr}$ ) was about $10-20 \%$ of postnatal levels.

Utilizing these control values, amniocentesis-derived diagnoses were confirmed in two fetuses with Tay-Sachs disease (TSD) and in another with $\mathrm{Gm}_{1}$-gangliosidosis type I. The disease-specific ganglioside $\left(\mathrm{Gm}_{2}\right.$ in TSD and $\mathrm{Gm}_{1}$ in $\mathrm{Gm}_{1}$-gangliosidosis) was significantly elevated in brain from each case (TSD, 5-6 times control values and Gmi-gangliodosis, approximately twice control values). In liver and kidney from the affected fetuses the disease-related enzyme activity of hexosaminidase $\mathrm{A}$ in TSD and $\beta$-galactosidase in $\mathrm{Gm}_{1}$-ganglactosidase) was less than $10 \%$ of control values. In liver, kidney, and brain extracts, cellulose-acetate gel electrophoresis of the disease-specific enzyme revealed no bands of enzyme activity for hexosaminidase $\mathrm{A}$ in Tay-Sachs disease or for the relevant $\beta$-galactosidase isoenzymes in $\mathrm{Gm}_{1}$-gangliosidosis.

\section{Speculation}

The prenatal diagnosis of Tay-Sachs disease, $\mathrm{Gm}_{1}$-gangliosidosis, and other sphingolipidoses may be confirmed in saline-aborted fetal tissues. Since abortion by hysterotomy may jeopardize the possibility of future pregnancy, saline-induced abortion may be preferable. An intriguing observation of this study was the presence of a $\beta$ galactosidase isoenzyme in brain from the $\mathrm{Gm}_{1}$ fetus. This isoenzyme was clearly different from the disease-specific enzyme and was not present in fetal Gm $\mathrm{Gm}_{1}$ liver or kidney or in postnatal type $I \mathrm{Gm}_{1}$ brain. This finding may indicate the presence of a tissue and age-specific $\beta$-galactosidase isoenzyme. 


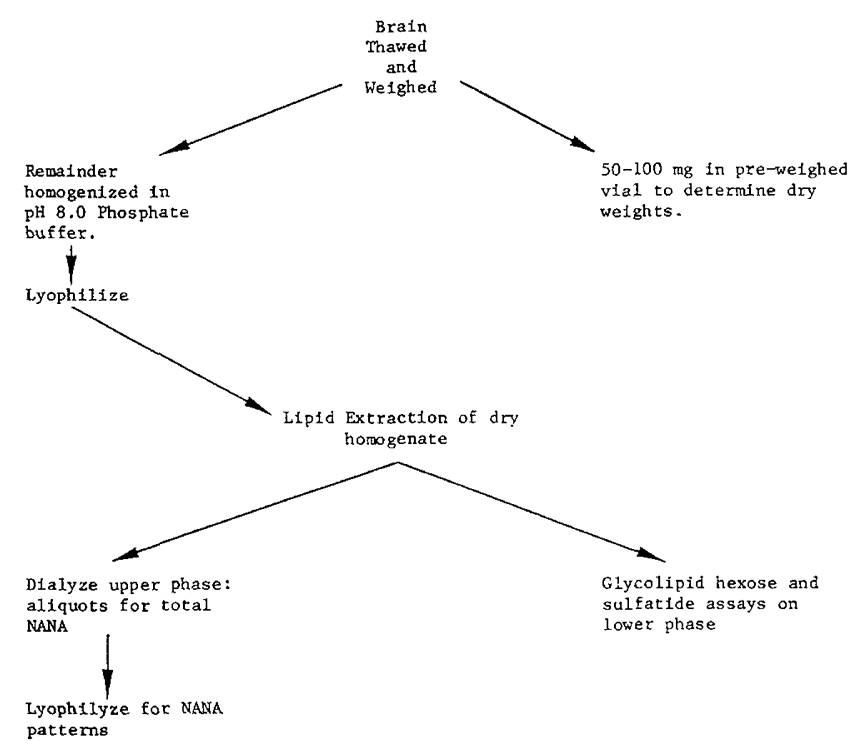

Fig. 1. Scheme for chemical analysis of fetal brain.

\section{Introduction}

Recent advances in understanding the biochemical abnormalities of inherited diseases have encouraged the monitoring of high risk pregnancies by amniocentesis to insure the birth of a phenotypically normal individual. A critical factor in this process is the ability to confirm the prenatal diagnosis in the aborted fetus. The majority of therapeutic abortions for genetic indications in this hospital are performed by intrauterine, hypertonic saline infusion. The saline infusion results in severe fetal maceration. Because control biochemical data from such fetuses are scarce, confirmation of the prenatal diagnosis might be obscured.

The sphingolipidoses are among the inherited diseases amenable to prenatal diagnosis [7]. In the present study we have established control values from chemical and biochemical analyses in saline- and nonsaline-aborted fetuses. The application of these methods has led to the confirmation of the amniocentesis-derived diagnoses in two cases of Tay-Sachs disease and in one case of $\mathrm{Gm}_{1}$-gangliosidosis type $I$.

\section{Materials}

Fetuses were obtained from saline abortion or hysterotomy and the tissues were removed and frozen $\left(-80^{\circ}\right)$ within $30 \mathrm{~min}$.

\section{Methods}

Chemical analyses. Brain (forebrain) was extracted as shown in Figure 1 according to previous methods
[19, 21]. Lipid-bound NANA was determined by the method of Svennerholm [20]. The ganglioside pattern was established by thin layer chromatography and individual fractions were identified by iodine vapor, isolated, and quantitated by NANA assay. Total lipid hexose [3] and sulfatide [11] were measured in the lower phase as described previously.

Enzyme analyses. Arylsulfatase A $[2,16]$ (metachromatic leukodystrophy), hexosaminidase [8, 15] (Tay-

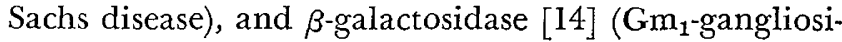
dosis) were assayed according to previous methods. Liver, kidney, and brain (forebrain) were homogenized in 10 volumes $0.05 \mathrm{~m}$ sodium phosphate-citric acid, $\mathrm{pH}$ 4.5 , and centrifuged $\left(4^{\circ}\right)$ at $1,000 \times g$ for $10 \mathrm{~min}$. The resulting supernatants were used for enzyme analyses. Protein was determined by the method of Eggstein and Kreutz [4].

\section{Gel Electrophoresis}

Hexosaminidase and $\beta$-galactosidase isoenzymes were examined by cellulose-acetate gel electrophoresis as described previously [18]. The appropriate derivatives of 4-methyl umbelliferone [24] were utilized as enzyme substrates. After incubation of gels overlayed with substrate-saturated filter paper at $37^{\circ}$, the gels were sprayed lightly with $0.25 \mathrm{M}$ glycine-sodium carbonate buffer, $\mathrm{pH}$ 10.7, and areas of enzyme activity could be visualized under ultraviolet light as fluorescent zones.

\section{Results}

\section{Chemical Analyses}

The water content of the brain was 88.3-91.5\% (Table I). There was no difference in this regard between saline-aborted fetuses and the nonsaline-aborted fetuses. Values for glycolipid hexose (lower phase) were similar in the nonsaline and saline fetuses. The glycolipid hexose values from the pathologic cases agreed with those from the control cases. Values for the sulfatides were $0.5-0.9 \mathrm{mg} / \mathrm{g}$ dry wt in the salineaborted fetuses and $0.2-0.4 \mathrm{mg} / \mathrm{g}$ dry wt in the hysterotomy-aborted fetuses. The lower values in the latter group may represent age differences. Sulfatide levels were also below the saline-control range in the TaySachs and $\mathrm{Gm}_{1}$-gangliosidosis brains. Lipid-bound NANA values from the affected fetuses were near the upper limit of the control range.

The pattern for the major gangliosides, assayed as NANA, is compared in Table II. Control values for 
Table I. Cerebral sphingolipid concentrations from human fetal brains

\begin{tabular}{|c|c|c|c|c|c|}
\hline & \multicolumn{2}{|c|}{ Control fetuses } & \multicolumn{2}{|c|}{ Tay-Sachs disease } & \multirow{2}{*}{$\begin{array}{l}\text { Generalized } \\
\text { gangliosidosis } \\
\text { yype I } \\
(22 \mathrm{wk})\end{array}$} \\
\hline & $\begin{array}{l}\text { Saline-aborted } \\
\text { fetuses } \\
(16-26 \mathrm{wk})\end{array}$ & $\begin{array}{c}\text { Nonsaline-aborted } \\
\text { fetuses } \\
(12-14 \mathrm{wk})\end{array}$ & $\begin{array}{l}\text { Case } 1 \\
\text { (22 wk) }\end{array}$ & $\begin{array}{l}\text { Case } 2 \\
(21 \mathrm{wk})\end{array}$ & \\
\hline Water, $\%$ & $88.5-90.5$ & $88.8-91.5$ & 88.9 & 89.6 & 88.3 \\
\hline Glycolipid hexose, mg/g dry wt & $4.1-5.0$ & $3.0-6.7$ & 4.5 & 3.5 & 4.0 \\
\hline Sulfatide, $\mathrm{mg} / \mathrm{g}$ dry $w \mathrm{t}$ & $0.51-0.86$ & $0.23-0.39$ & 0.45 & 0.25 & 0.30 \\
\hline Total lipid NANA, ${ }^{2} \mathrm{mg} / \mathrm{g}$ dry wt & $1.1-3.3$ & $1.3-3.1$ & 3.2 & 2.7 & 2.8 \\
\hline
\end{tabular}

1 Three fetuses.

${ }^{2}$ NANA : $N$-acetyl neuraminic acid.

Table II. Distribution of gangliosides from human fetal brains ${ }^{1}$

\begin{tabular}{|c|c|c|c|c|}
\hline & $\begin{array}{l}\text { Saline-aborted } \\
\text { fetuses? }\end{array}$ & $\begin{array}{l}\text { Tay- } \\
\text { Sachs } \\
\text { case } 1\end{array}$ & $\begin{array}{l}\text { Tay- } \\
\text { Sachs } \\
\text { case 2 }\end{array}$ & $\mathrm{Gm}_{1}$ \\
\hline Gestational age, wk & $16-26$ & 22 & 21 & 22 \\
\hline $\mathrm{Gm}_{2}$, molar $\%$ & $6(4-9)$ & 40 & 35 & 9 \\
\hline $\mathrm{Gm}_{1}$, molar $\%$ & $21(17-24)$ & 13 & 15 & 35 \\
\hline $\begin{array}{l}\text { GDla + GDlb + GTl, } \\
\text { molar } \%\end{array}$ & $72(70-77)$ & 47 & 50 & 56 \\
\hline
\end{tabular}

${ }^{1}$ Control values represent mean and range for each group. GDla and GDlb: major disialogangliosides; GT1: major trisialoganglioside.

2 Three fetuses.

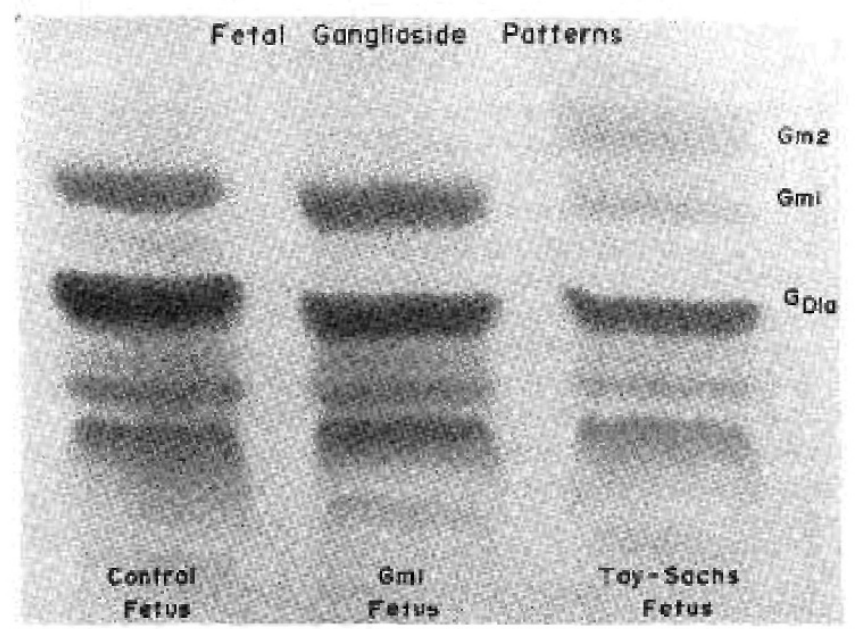

Fig. 2. Thin layer chromatogram of ganglioside pattern in fetal brain. Equivalent amounts of lipid-bound $N$-acetyl neuraminic acid were applied in each lane.

saline- and nonsaline-aborted fetuses are in general agreement. The significant features in the diseased fetuses (Table II and Fig. 2) are the increase in the disease-related ganglioside, this is, $\mathrm{Gm}_{2}$ in Tay-Sachs disease and $\mathrm{Gm}_{1}$ in $\mathrm{Gm}_{1}$-gangliosidosis, and a moder- ate decrease in the more complex gangliosides. In the Tay-Sachs fetuses, $\mathrm{Gm}_{2}$ is increased five to six-fold above control values. Our $\mathrm{Gm}_{2}$ control values agree with those of Navon and Padeh [12], but are approximately twice those reported by O'Brien et al. [13]. The $\mathrm{Gm}_{1}$ level in the $\mathrm{Gm}_{1}$-gangliosidosis fetus was increased by nearly $100 \%$. In all three pathologic cases, there was a reduction of di- and trisialic acid (NANA) gangliosides when compared with the saline or nonsaline control values.

\section{Enzyme Analyses}

The specific activities of ARA, $\beta$-galactosidase, and hexosaminidase, as well as values for hexosaminidase A (defined by heat inactivation), are presented in Table III for liver, kidney, and brain. In each tissue the values for ARA and $\beta$-galactosidase were similar in saline- and hysterotomy-aborted tissue. Hexosaminidase-specific activities were greater in hysterotomy-derived tissues than in saline-aborted tissues. However, hexosaminidase $\mathrm{A}$, by heat inactivation, was similar in each tissue. In the liver and kidney from the Tay-Sachs fetuses, hexosaminidase activities agreed with control values for saline-aborted fetuses, whereas values from Tay-Sachs fetal brain were slightly greater than control values for saline-aborted fetuses. Hexosaminidase A activity was virtually absent in Tay-Sachs liver and kidney (Table II). The ARA and $\beta$-galactosidase specific activities of fetal Tay-Sachs tissues were within control ranges. In tissues from the $\mathrm{Gm}_{1}$-gangliosidosis fetus, $\beta$-galactosidase activity was markedly reduced whereas values for the other enzymes agreed with control values.

Because of high percentage of heat-inactivatable hexosaminidase found in the Tay-Sachs fetal brain, the hexosaminidase isoenzymes were examined by cellu- 
Table III. Hydrolase specific activities in fetal liver, kidney, and brain

\begin{tabular}{|c|c|c|c|c|c|}
\hline \multirow[t]{2}{*}{$\therefore$} & \multicolumn{2}{|c|}{ Control fetuses ${ }^{1}$} & \multirow{2}{*}{$\begin{array}{l}\text { Tay-Sachs } \\
\text { case } 1\end{array}$} & \multirow{2}{*}{$\begin{array}{l}\text { Tay-Sachs } \\
\text { case } 2\end{array}$} & \multirow[b]{2}{*}{$\mathrm{Gm}_{1}$} \\
\hline & Saline-aborted & Hysterotomy & & & \\
\hline \multicolumn{6}{|l|}{ Liver } \\
\hline Arylsulfatase $A$, sp act $^{2}$ & $23-67$ & $40-51$ & 46 & 47 & 35 \\
\hline$\beta$-Galactosidase, sp act ${ }^{2}$ & $106-665$ & $134-375$ & 206 & 269 & 20 \\
\hline Total hexosaminidase, sp act ${ }^{2}$ & $2,198-3,051$ & $3,209-3,429$ & 2,394 & 2,338 & 1,608 \\
\hline Hexosaminidase $\mathrm{A}, \%^{3}$ & 35 & $33-41$ & 5 & 2 & 22 \\
\hline \multicolumn{6}{|l|}{ Kidney } \\
\hline Arylsulfatase $\mathrm{A}, \mathrm{sp} \mathrm{act}^{2}$ & $13-21$ & $11-20$ & 5 & 3 & 36 \\
\hline$\beta$-Galactosidase, sp act ${ }^{2}$ & $310-397$ & $505-934$ & 330 & 349 & 29 \\
\hline Total hexosaminidase, sp act ${ }^{2}$ & $2,376-5,001$ & $4,015-9,103$ & 2,145 & 2,241 & 2,354 \\
\hline Hexosaminidase $\mathrm{A}, \%^{3}$ & $36-47$ & $20-58$ & 4 & 2 & 26 \\
\hline \multicolumn{6}{|l|}{ Brain } \\
\hline Arylsulfatase $A$, sp act ${ }^{2}$ & $13-24$ & $1-16$ & $3^{4}$ & 6 & 5 \\
\hline$\beta$-Galactosidase, $\mathrm{sp} \mathrm{act}{ }^{2}$ & $77-81$ & $66-184$ & $121^{4}$ & 81 & 42 \\
\hline Total hexosaminindase, sp act ${ }^{2}$ & $406-658$ & $737-1259$ & $839^{4}$ & 1,160 & 758 \\
\hline Hexosaminidase $\mathrm{A}, \%^{3}$ & $60-62$ & $66-75$ & $50^{4}$ & 42 & 53 \\
\hline
\end{tabular}

Three fetuses.

${ }^{2}$ Specific activities are expressed in nanomoles of substrate cleaved per milligram of soluble protein per hour and represent the average of at least three determinations.

${ }^{3}$ Hexosaminidase $\mathrm{A}$ is expressed as percentage of heat inactivation at $52^{\circ}$.

${ }^{4}$ Represents values obtained from cerebellum.

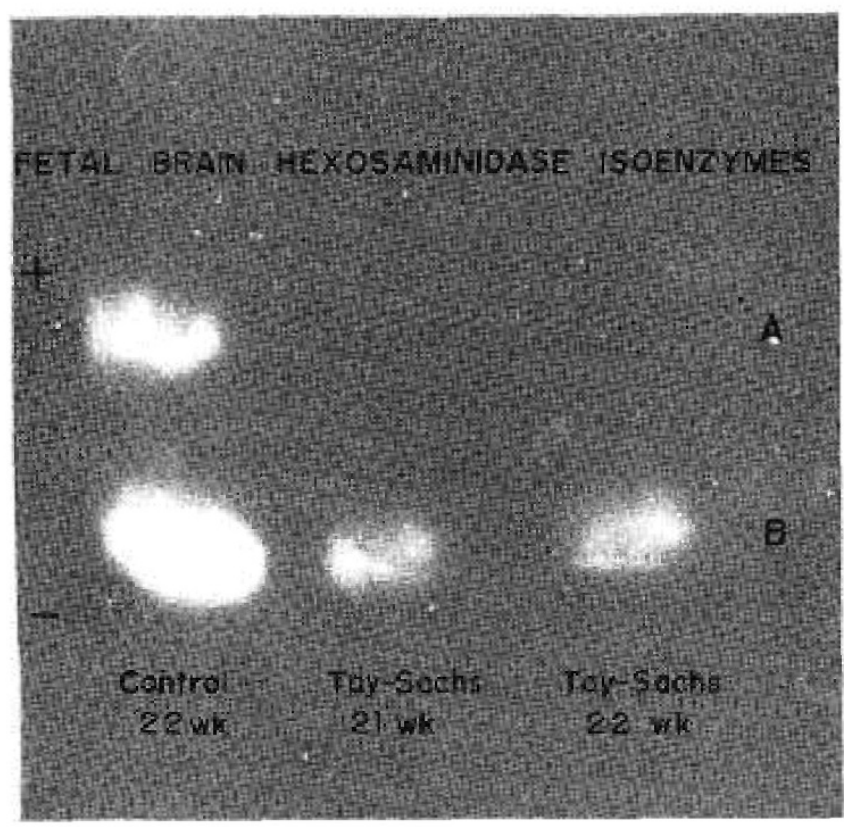

Fig. 3. Cellulose-acetate gel electrophoresis of hexosaminidass isoenzymes (see Methods). Hexosaminidase A isoenzyme is absent in brains of fetuses with Tay-Sachs disease. Hexosaminidase A is disease-rclated isoenzyme in Tay-Sachs disease.

lose-acetate gel electrophoresis. In each Tay-Sachs fetus, the hexosaminidase $\mathrm{A}$ band was absent in brain (Fig. 3), liver, and kidney. The apparent discrepancy between the enzyme analysis and gel electrophoresis may be explained by failure to achieve optimum conditions for heat-inactivation using brain extracts. The critical importance of these conditions is well known [8]. Brain $\beta$-galactosidase values in the $\mathrm{Gm}_{1}$ fetus were about $50 \%$ of control values. When aliquots of brain were examined by gel electrophoresis, isoenzymes $\mathrm{A}$ and $\mathrm{B}$ were not visualized. A zone of fluorescence was visible at the origin and apparently accounts for $\beta$-galactosidase activity in $\mathrm{Gm}_{1}$ brain. None of the $\beta$-galactosidase isoenzymes could be visualized in kidney or liver extracts from the $\mathrm{Gm}_{1}$ fetus [10].

\section{Comment}

The confirmation of amniocentesis-derived diagnosis in aborted fetuses is an important aspect of genetic counseling. Saline-induced abortion offers advantages over hysterotomy, as evidence exists that this latter procedure may jeopardize the possibility of future pregnancies [23]. The present study compares chemical and biochemical data from saline- and nonsalineaborted fetuses. Sphingolipid analyses from brain yielded similar results in each group with the exception that sulfatide values were lower in the nonsaline group. This discrepancy could be explained by age differences, inasmuch as the nonsaline group was aborted earlier in gestation.

The values for lipid-bound hexose and lipid-boundNANA compare favorably with Svennerholm's data 
[21]. The ganglioside distribution, in terms of molar percentages of the major gangliosides, also agrees with published values [22]. Enzyme data obtained from fetal liver, kidney, and brain provided an interesting comparison of the two groups of abortuses (Table III). The specific activities of the three enzymes assayed were generally similar in the two control groups. Arylsulfatase $\mathrm{A}$ was of special interest because the specific activities were rather low in both the saline and nonsaline group. Fetal values were $10-20 \%$ of those from postnatal tissues, that is, the fetal values would be near the "disease" range for metachromatic leukodystrophy if compared to postnatal tissues only [1]. Previous information has indicated that the specific activity of arylsulfatase $\mathrm{A}$ increases dramatically with maturation $[5,6,9,17]$. Failure to consider that arylsulfatase $\mathrm{A}$ is a developmental enzyme could lead to false conclusions in the course of evaluating a suspected fetus for metachromatic leukodystrophy.

During this study, we had the opportunity to examine tissue from two saline-aborted fetuses with the amniocentesis-derived diagnosis of classical Tay-Sachs disease and one with the diagnosis of $\mathrm{Gm}_{1}$-gangliosidosis type $I$. We were able to confirm these diagnoses on analytic and enzymatic grounds. The utilization of saline-aborted tissues for studies of this type is clearly feasible and in view of the acknowledged limitations of hysterotomy, would seem preferable where future pregnancies are contemplated.

\section{Summary}

Chemical and biochemical variables of the sphingolipids were compared in saline- and hysterotomy-aborted tissues. In general, the data were similar in liver, kidney, and brain, respectively, in each group and support the utilization of saline-aborted tissue for the confirmation of amniocentesis-derived diagnosis. It is suggested that this form of abortion may be preferable since hysterotomy abortion may endanger the successful completion of future pregnancy.

These data provided the basis for confirmation of the antenatal diagnosis of two fetuses with Tay-Sachs disease and one with $\mathrm{Gm}_{1}$-gangliosidosis type I. In the last fetus, an unusual brain $\beta$-galactosidase isoenzyme was noted, and it is suggested that this isoenzyme may be both a tissue and age-specific $\beta$-galactosidase.

\section{References and Notes}

1. Austin, J., Armstrong, D., And Shearer, L.: Metachromatic form of diffuse cerebral sclerosis. Arch. Neurol., 13: 593 (1965).
2. Baum, H., Dodgson, K. S., And Spencer, B.: The assay of arylsulfatases $\mathrm{A}$ and $\mathrm{B}$ in human urine. Clin. Chim. Acta, 4: 453 (1959).

3. Dubors, M., Gilles, K. A., Hamilton, J. K., Rebers, P. A., AND SMITH, F.: Colorimetric method for determination of sugars and related substances. Anal. Chem., 28: 350 (1956).

4. EgGstein, M., And Kreutz, F.: Klin. Wochschr., 33: 879 (1955).

5. Heringova, A., Koldovsky, C., Yaffe, S. J., Jinsova, V., AND UhER, J.: Sulfatase activity in placenta, liver, and small intestine of human fetuses. Biol. Neonatorum., 14: 265 (1969).

6. JATzkewrtz, H.: Cerebral sphingolipidoses as inborn errors of metabolism. In: J. D. Allan and D. N. Raine: Some Inherited Disorders of Brain and Muscle, p. 114 (E. \& S. Livingstone, Ltd., Edinburgh and London, 1969).

7. Kaback, M. M., AND Howell, R. R.: Heterozygote detection and prenatal diagnosis of lysosomal diseases. In: H. G. Hers and F. Van Hoof: Lysosomes and Storage Diseases, Chapt. 26 (Academic Press, New York, in press).

8. KABACK, M. M.: Hexosamindase A: Applications in carrierstate identification and diagnosis of Tay-Sachs disease. Methods of Enzymology, Vol. 5 (Academic Press, New York, 1972).

9. Kaback, M. M., Percy, A. K., And Kasselberg, A. G.: In vitro studies in sulfatides lipidosis. In: B. Volk and S. M. Aronson: Sphingolipids, Sphingolipidoses, and Allied Disorders, p. 451 (Plenum Press, New York, 1972).

10. Kaback, M. M., Sloan, H. R., Herndon, R. M., and Percy, A. $\mathrm{K} .: \mathrm{Gm}_{1}$-gangliosidosis, type I: In utero detection and fetal manifestations. J. Pediat., 82: 1037 (1973).

11. KEAN, E. L.: Rapid, sensitive spectrophotometric method for quantitative determination of sulfatides. J. Lipid Res., 9: 319 (1968).

12. Navon, R., and Padeh, B.: Prenatal diagnosis of Tay-Sachs genotypes. Brit. Med. J., 4: 17 (1971).

13. O’Brien, J. S., Okada, S., Fillerup, D. L., Veath, M. L., Adornato, B., Brenner, P. H., And Leroy, J. G.: Tay-Sachs disease: Prenatal diagnosis. Science, 172: 61 (1971).

14. OKADA, S., AND O'BRIEN, J. S.: Generalized gangliosidosis: Beta-galactosidase deficiency. Science, 160: 1002 (1968).

15. Okada, S., ANd O'Brien, J. S.: Tay-Sachs disease: Generalized absence of a beta-D- $N$-acetylhexosaminidase component. 165: 698 (1969).

16. Percy, A. K., AND KABACK, M. M.: Infantile and adult-onset metachromatic leukodystrophy. New Engl. J. Med., 285: 785 (1971).

17. Percy, A. K., AND Yaffe, S. J.: Sulfate metabolism during mammalian development. Pediatrics, 33: 965 (1964).

18. Rattazzi, M. C., and Davidson, R. G.: Tay-Sachs disease: Limitations of amniocentesis for the antenatal diagnosis. Amer. J. Human Genet., 22: 41a (1970).

19. SuzuKI, K.: The pattern of mammalian brain gangliosides. $J$. Neurochem., 12: 629 (1965).

20. Svennerholm, L.: Chromatographic separation of human brain gangliosides. J. Neurochem., 10: 613 (1963).

21. Svennerholm, L.: The distribution of lipids in the human nervous system. J. Neurochem., 11: 839 (1964).

22. Vanier, M. T., Holm, M., Ohman, R., ANd Svennerholm, L.: Developmental profiles of gangliosides in human and rat brain. J. Neurochem., 18: 581 (1971).

23. Wilson, J. R., Beecham, C. T., and Carrington, E. R.: Ob- 
stetrics and Gynecology, Ed. 4, p. 466 (C. V. Mosby Co., St. Louis, 1971).

24. Koch-Light, Ltd., Colmbrook, Buckinghamshire, U. K.

25. The current address of Dr. Alan K. Percy is: Department of Pediatrics, Charles R. Drew Postgraduate Medical School, Los Angeles, Calif. 90059. He is recipient of Teacher-Investigator Award no. 11,016, United States Public Health Service.

26. The current address of Dr. Michael M. Kaback is: Department of Pediatrics, UCLA, Harbor General Hospital Campus, 1000 W. Carson St., Torrance, Calif. 90509. He is a Joseph
P. Kennedy, Jr., Memorial Foundation Research Scholar in Mental Retardation.

27. This research was supported by a grant from the John A. Hartford Foundation, Inc., from the National FoundationMarch of Dimes, and the John F. Kennedy Institute TaySachs Disease Fund.

28. Requests for reprints should be addressed to: Alan K. Percy, M.D., Department of Pediatrics, Charles R. Drew Postgraduate Medical School, Los Angeles, Calif. 90059 (USA).

29. Accepted for publication May 30, 1973. 